\title{
Paleomagnetic study of the Late Jurassic formations in Northern Qaidam basin and tectonic implications
}

\author{
Shoumai Ren\#*, Zhenyu Yangt, Zhiming Sun† and J unling Pei† \\ †Institute of Geomechanics, ChineseAcademy of Geological Sciences, Beijing, 100081, CHINA \\ ¥Strategi c Research Center for Oil and Gas Resources, Ministry of Land \& Resources, Beijing, 100034, CHINA \\ * To whom correspondence should be addressed. E-mail: realshaw@vip.sina.com
}

According to the paleomagnetic study from the Upper Jurassic red beds along the Altyn Tagh Fault, some researchers suggest that the Jurassic blocks in the Altyn Tagh Fault show significant relative clockwise rotation with respect to Tarim basin $\left(16.2^{\circ} \pm 11.2^{\circ}\right)$, but they also point out whether this rotation was representative of the whole Qaidam basin or was of a local character (Halim et al. 2003). In order to understand thetectonic evolution of the Qaidam basin in Late Jurassic and to confirm this rotation, we carried out the paleomagnetic study on the Upper Jurassic red and brown mudstones collected at seven sites near the Lulehe profile $\left(38.15^{\circ} \mathrm{N}, 94.69^{\circ} \mathrm{N}\right)$ in the northern Qaidam basin. Thermal demagnetization up to $685^{\circ} \mathrm{C}$ shows both low- and high- temperature components (LTC and HTC, respectively). LTC lie close to the recent geomagnetic field and seem to be a recent overprint. The HTC, carried principally by haematiteand presenting a solereverse polarity, passed thefold test at the 95 per cent confidencelevel. The palaeomagnetic pole calculated from the tilt-corrected six sites mean direction $\left(D_{\mathrm{s}}=\right.$ $\left.216.6^{\circ}, I_{\mathrm{s}}=-20.4^{\circ}, \alpha_{95}=14.0^{\circ}\right)$ is situated at $47.2^{\circ} \mathrm{N}, 215.1^{\circ} \mathrm{E}(\mathrm{dp} /$ $\mathrm{dm}=7.7 / 14.7)$. The comparison of this result with coeval paleomagnetic poles from the western Qaidam basin $\left(50.1^{\circ} \mathrm{N}\right.$, $\left.198.0^{\circ} \mathrm{E}, \mathrm{dp} / \mathrm{dm}=5.0 / 8.6\right)$ reveals no obvious rotation $\left(5.4^{\circ}+13.1^{\circ}\right)$ during Late Jurassic. This study also suggests that the Qaidam basin was likely one block and could have rotated as a whole in the Late Jurassic. The differences of palaeolatitude $\left(8.2^{\circ}\right)$, while the present location issimilar, perhaps is theresult that theAltyn Tagh Faults, which were strike-slipping as left-lateral since the Late Mesozoic (Liu et al. 2001). Comparing this study to the coetaneous palaeomagnetic poles from Tarim, the North China
Block and the Eurasia (Table 1), the results suggest that northward convergence of theQaidam block exists with respect to Tarim $\left(14.3^{\circ}+13.3^{\circ}\right)$ since Late Jurassic, unlike the previous literature $\left(4.5^{\circ} \pm 8.2^{\circ}\right)$. A significant relative clockwise rotation of the Lulehe area with respect to Tarim basin seem to have occurred $\left(11.1^{\circ}+13.9^{\circ}\right)$ without doubt. The overall NS convergence absorbed between Qaidam basin and Eurasia is $29.0^{\circ}+14.0^{\circ}$, whereas that absorbed between the Qaidam and the NCB is $17.1^{\circ}+12.2^{\circ}$. As mentioned in the previousliteratures, we also think that the latter value is the result of the India-Asia collision, but the magnitude of convergence is not known.

\section{References}

Halim N, Y Chen and JP Cogné. 2003. A first palaeomagnetic study of Jurassic formationsfrom the Qaidam basin, Northeastern Tibet, China-tectonic implications. Geophys J Int 153: 20-26

Liu YJ, HW Ye, XH Ge W Chen, IL Liu, SHM Ren and HX Pan. 2001. Laser probe ${ }^{40} \mathrm{Ar} /{ }^{39} \mathrm{Ar}$ dating of mica on the deformed rocks from Altyn Fault and its tectonic implications, western China. ChineseScienceBulletin 46(4): 322-325

Gilder S and V Courtillot. 1997. Timing of the North-South China collision from New Middle to Late Mesozoic palaeomagnetic data from the North China Block.J Geophys Res 102: 17713-27

Li YP, ZK Zhang, M McWilliams, R Sharps, Y] Zhai, YA Li, Q Li and A Cox. 1988. Mesozoic palaeomagnetic results of the Tarim craton: tertiary relative motion between China and Siberia. Geophys Res Lett 15: 21720

BesseJ and V Courtillot. 1991. Revised and synthetic apparent polar wander path of the African, Eurasian, North American and Indian plates, and the ture polar wander since $200 \mathrm{Ma}$.J Geophys Res 96: 4029-50

TABLE 1. Selected palaeopoles used for comparisons

\begin{tabular}{lllllllll}
\hline Block & Age & Lat & Long. & $\boldsymbol{\lambda} \mathbf{p}$ & $\boldsymbol{\phi p}$ & $\boldsymbol{p} \boldsymbol{\lambda}$ & $\begin{array}{l}\boldsymbol{A}_{\mathbf{9 5}} \\
\text { (dp/dm) }\end{array}$ & Reference \\
\hline Eurasia & $140 \mathrm{Ma}$ & - & - & 71.6 & 173 & - & 10.4 & Besse \& Courtillot, 1991 \\
\hline Qaidam(Huatugou) & $\mathrm{J}_{3}$ & 38.46 & 90.75 & 50.1 & 198.0 & 19.2 & $5.0 / 8.6$ & Halim et al., 2003 \\
\hline Qaidam(Lulehe) & $\mathrm{J}_{3}$ & 38.15 & 94.69 & 47.2 & 215.1 & 10.5 & $7.7 / 14.7$ & This study \\
\hline North China & $\mathrm{J}_{3}$ & 31.6 & 116.0 & 74.4 & 222.8 & 26.0 & 5.9 & Gilder \& Courtillot, 1997 \\
\hline Tarim & $\mathrm{J}_{3}$ to $\mathrm{K}_{1}$ & 42.0 & 81.6 & 64.6 & 208.9 & 24.3 & 9.0 & Li et al.1988 \\
\hline
\end{tabular}

